\title{
Correction: Valvular Endothelial Cell Response to the Mechanical Environment-A Review
}

\author{
Nandini Deb ${ }^{1}$ Carla M. R. Lacerda $\mathbb{1}^{1}$
}

Published online: 26 November 2021

(c) Springer Science+Business Media, LLC, part of Springer Nature 2021

Correction to: Cell Biochemistry and Biophysics (2021) 79, 695-709 https://doi.org/10.1007/s12013-021-01039-z

In this article the affiliation details of co-author Dr. Nandini Deb were incorrectly given as "Jasper Department of
Chemical Engineering, The University of Texas at Tyler, 3900 University Blvd, Tyler 75799 TX, US" but should have been "Department of Chemical Engineering, Texas Tech University, Lubbock 79409-3121 TX, US”. 